Ferenc Laczó, Máté Zombory

\title{
BETWEEN TRANSNATIONAL EMBEDDEDNESS \\ AND RELATIVE ISOLATION: \\ THE MODERATE RISE OF MEMORY STUDIES \\ IN HUNGARY
}

\author{
I \\ INTRODUCTION
}

As we started writing this study, the current Hungarian Government announced its intention to establish a Committee of National Memory to deal, above all, with the communist epoch. This officially endorsed new committee will ambition to reorient the ongoing disputes over the crimes of communism and their perpetrators, and hopes to settle the most controversial questions in a conclusive manner. Without being explicit about this, Hungary thereby follows in the footsteps of other post-communist countries where institutes with nearly identical names and relatively similar agendas, such as the Polish Institute of National Remembrance (Instytut Pamięci Narodowej) or the Slovak Institute of National Memory (Ústav Pamäti Národa), have already been in operation for a number of years. The Hungarian governmental decision was announced on 19 March 2012, but the Committee is still about to get established and details concerning it have not been made public yet - unless something unexpected occurs, both will have happened by the time our paper appears in print though. ${ }^{1}$

${ }^{1}$ The background story to the foundation of this committee is, in brief terms, the following: while Fidesz has been strongly devoted to an anticommunist narrative of Hungarian history for at least a decade now, epitomised by the controversial House of Terror which opened exactly a decade ago when Viktor Orbán enjoyed his first mandate as prime minister, the recent oppositional proposal to allow greater access to information about agents and files of the state security of the communist dictatorship threatened to damage its credentials in this regard. Fidesz namely rejected the oppositional proposal and only after some internal disputes did it eventually decide to endorse a new way of trying to 'manage the national past'. 
The transnational semantic shift towards the seemingly evermore-frequent and inflated use of the concept 'memory' has thus just resulted in its institutionalisation on the very top level in Hungary - even if this occurred with some delay as compared to other East-Central-European countries. ${ }^{2}$ On the other hand, the way the concept is used here arguably does not refer to memory in the strict sense at all. It indeed remains entirely doubtful whether memory studies will play a significant role in the workings of the Committee of National Memory.

In the way such official canonisation of the concept will not necessarily directly result in memory research, we shall argue that despite the great interest in personal identity and memory in its various representational forms observable in recent decades and the evident transnational embeddedness of Hungarian discussions, the rise of memory studies has been of rather modest proportions here. The transformation of Hungarian scholarship and particularly of historiography is partial: Hungarian memory studies currently seem to be stuck somewhere between transnational embeddedness and relative isolation. Next to recurrent references to international classics, there is little reception of contemporary international scholarship. The participation of Hungarian scholars and the proportion of Hungarian topics in international discussions also leave something to be desired.

Our paper is divided into five parts. In order to contextualise our analysis of recent trends, we shall devote some lines to the

${ }^{2}$ While the transnational dimension of this linguistic shift towards memory leading to the expansion and inflation of the concept has been remarked before, in-depth comparisons with changing use in more minor languages such as Hungarian are still missing. Such comparisons would have to address the moot question of how various concepts such as realms of memory (lieux de mémoire), memory culture (Erinnerungskultur) and national memory (nemzeti emlékezet) acquired varying degrees of prominence in different European languages as well as how they are simultaneously present and similarly important in more 'minor' cultures where international reception plays a greater role than in 'major' cultures. We strongly believe that European discussions could greatly benefit from such comparisons and the resulting more nuanced semantic awareness. We would also claim that the lack of such comparative semantic explorations has to do with the fact that native speakers of major European languages (such as English, French and German) tend to be overrepresented in scholarly discussions of European issues. See, e.g., Muriel Blaive, Christian Gerbel and Thomas Lindenberger (eds.), Clashes in European Memory: The Case of Communist Repression and the Holocaust (Vienna, 2011). 
historical context of the memory boom at the end of the last century. Second, we will discuss the intellectual foundations of memory studies in Hungary. We shall devote special attention to the reception of international scholarship and ask what the most common theoretical and methodological references are. We shall address the current status of memory studies too: to what extent had it successfully become a mainstream part of historical studies and what is the specific disciplinary profile of Hungarian researches? Third, we shall ambition to highlight the main thematic clusters of memory studies, presenting some of the most important research projects and their key findings. Last but not least, we shall discuss the relations between national, regional and European memory studies, briefly reflecting on the potential reasons behind the relative isolation of Hungarian memory studies.

II

\section{THE RHETORIC OF RECOVERY AND THE REINVENTION OF MEMORY}

As James Mark recently pointed out, not only were there both internal political drives and external expectations to confront the recent past in post-communist Central and Eastern Europe but they largely coincided with the 'memory boom'. ${ }^{3}$ Arguably for rather contingent reasons of temporal coincidence, regime change and the multilayered reinvention of memory were deeply intertwined processes. Eastern European memorians (Carol Gluck) in post-communist Eastern Europe were clearly part of the transnational transformation of historical cultures (such as the increased attention devoted to the Holocaust and the rise of the discussion on the crimes of communism), but their contributions were also embedded in specific local historical-political contexts best studied through the methods of comparative history. ${ }^{4}$

\footnotetext{
${ }^{3}$ James Mark, The Unfinished Revolution: Making Sense of the Communist Past in Central-Eastern Europe (New Haven, 2010).

${ }^{4}$ Carol Gluck, Past Obsessions: World War Two in History and Memory (New York, forthcoming). On historical cultures, see Jörn Rüsen, 'Was ist Geschichtskultur? Überlegungen zu einer neuen Art, über Geschichte nachzudenken', in idem, Theo Grütter and Klaus Füßmann (eds.), Historische Faszination. Geschichtskultur heute (Cologne, 1994), 3-26; Jörn Rüsen, Historische Orientierung. Über die Arbeit des Geschichtsbewußtseins, sich in der Zeit zurechtzufinden (Cologne, 1994).
} 
In short, transnational and comparative approaches are both useful and even necessary to understand these transformations.

A main trend after the decline of the communist teleology of history with its utopistic visions of the future has been to reestablish traditions, revisit the past and devote particular attention to the dictatorial repressions (the gross human rights violations in the newly dominant idiom) of the twentieth century. ${ }^{5}$ In Hungary, the mainstream idea right after 1989 was to confront recent historical developments and inquire why they led to various dead-ends so that a novel, normatively charged vision of national history could emerge. ${ }^{6}$ The historical pantheon of heroes was gradually largely replaced by a canon centred on victims. Accordingly, the status of witnesses was elevated and their memories were authorised. In other words, the acquisition of freedom and the new sense of victimhood were closely connected: the new freedoms to remember often led to the recall of suffering. ${ }^{7}$ Hungary is no special case in these regards: these are transnational trends with even wider geographical reach than postcommunist Central and Eastern Europe.

In Hungary, more specifically, the fall of communism and the supposed recovery of national memory were closely intertwined from the very beginning. The conventional narrative about the changes in 1989 namely focuses on the reinterpretation of 1956 that culminated in the reburial of Imre Nagy and his fellow victims on 16 June 1989 - executed during the reprisals after 1956 more than three decades earlier, these victims were buried in unmarked graves and were meant to be forgotten. Their so called reburial, which was in fact their first proper burial, is frequently identified with the symbolic burial of communist legitimacy. According to this mainstream narrative, the

${ }^{5}$ On the mass utopias of the 20th century, see Susan Buck-Morss, Dreamworld and Catastrophe: The Passing of Mass Utopia in East and West (Cambridge, MA, 2002). On the rise of human rights, see Samuel Moyn, The Last Utopia: Human Rights in History (Cambridge, MA, 2010).

${ }^{6}$ Concerning the 'dead-ends' of Hungarian history, the reflections of István Bibó ought to be mentioned. See idem, 'Deformierter ungarischer Charakter. Ungarische Geschichte auf Irrwegen', trans. Béla Rásky, available at <http://www. kakanien.ac.at/beitr/fallstudie/IBibol.pdf.> [Accessed 18 May 2012]. On Bibó, now see Balázs Trencsényi, A nép lelke. Nemzetkarakterológiai viták Kelet-Európában (Budapest, 2011).

${ }^{7}$ This statement is made in Péter György, Apám helyett (Budapest, 2011). 
delegitimation of the communist system was a consequence of the recovery of historical truth, which was in turn practically equated with the regaining of previously forcibly suppressed national memory.

1989 is thus also often seen as a turning point in the process of social remembrance when the future-oriented and past-erasing decades of Kádárism with its enforcement of 'all-national psychological suppression' (Ferenc Mérei), 'societal amnesia' (Péter György) and memory gaps gave way to recovery and the new dignity of victims. ${ }^{8}$ While the central points of the key symbolic event of 1989 were indeed retroactive symbolic justice and giving voice to what had been suppressed, this chronology of the recovery of memory closely follows the dates of the grand narrative of political history. As such, it is unable to capture the intricacies of the actual historical process.

This neat narrative is much complicated by the fact that the rise of interest in the remembrance of historical events in many ways predated 1989. The history of Hungarian historical documentary film using many oral history interviews, for instance, reveals that already prior to 1989 there was substantial and rather explicit interest in sensitive historical topics including such politically charged issues as Stalinist crimes. ${ }^{9}$ The golden decade of historical documentaries was the 1980s when they in all likelihood could count on greater audiences and had a greater societal impact than after $1989 .{ }^{10}$ While Jewish history and the history of the Holocaust were officially largely tabooed under communism, several semi-official oral history ventures conducted interviews with Holocaust survivors already at this time. ${ }^{11}$

${ }^{8}$ Idem, Néma hagyomány: kollektív felejtés és a kései múltértelmezés: 1956 1989ben (A régmúlttól az örökségig) (Budapest, 2000). On memory gaps and their functioning, see Lutz Niethammer, 'Was haben Sie am 17. Juni gemacht? Oder die Nische im Gedächtnis', in Kulturwissenschaftliches Institut Nordrhein-Westfalen: Das Gründungsjahr. Bericht 1990 (Essen, 1991).

${ }^{9}$ Réka Sárközi, Elbeszélt múltjaink. A magyar történelmi dokumentumfilm útja (Budapest, 2011).

10 The mainstream function of documentaries had before 1989 was arguably taken over by new historical museums after 1989 - or at least analyses of historical cultures prefer to devote extensive attention to them. The two most famous (though in many ways radically different) such museums in Hungary are the House of Terror and the Holocaust Memorial Centre in Budapest.

${ }^{11}$ Ferenc Erős and András Kovács, 'The Biographical Method in the Study of Jewish Identity in Present-day Hungary', in Tamás Hofer and Péter Niedermüller (eds.), Life History as a Cultural Construction/Performance (Budapest, 1988), 345-56; 
Moreover, even personal testimonies concerning the events of 1956 , the most sensitive political subject and the greatest source of anxiety and discomfort for the regime, were gathered throughout the 1980s in what later became the (justly famous) Oral History Archive of the 1956 Institute.

While there was thus significant interest in 'recovering memory', there was little theoretical reflection on methods through which it can be accessed and the appropriate scholarly manner it should be studied. ${ }^{12}$ Much rather, memory was often simply viewed as a crucial means of accessing and dealing with the past: the chance to articulate 'unfalsified memories' was seen as central to the knowledge of 'historical truth' and the continuity of national history on the one hand, and the reestablishment of the continuity of seemingly broken lives and the regaining of personal integrity on the other. The trend of thinking of the recalled past in an objectivistic manner, i.e. seeing in it primarily an essential tool to reconstruct what actually happened, continued even in the otherwise drastically transformed situation after 1989 to which we now turn.

\section{III}

\section{THE RISE OF MEMORY STUDIES: RECEPTION AND AGENDAS}

While oral history researches were conducted and memory studies (avant la lettre) were even, to some extent, institutionalised in Hungary before 1989, relations to the past as well as the Hungarian scholarly field got radically transformed in the wake of the dissolution of the communist regime. We cannot go into details here about the ways Hungarian scholarship has been institutionally, personally and financially restructured in recent decades. ${ }^{13}$ Modern Hungarian

on these projects today, see Éva Kovács, András Lénárt and Anna Lujza Szász, 'A magyar holokauszt személyes történetének digitális gyüjteményei', Buksz, xxiii, 4 (2011), 336-51.

${ }^{12}$ For a theoretical elaboration on the spatial dimension of social remembrance, and its empirical application on commemorative self-narration practices, see Máté Zombory, Maps of Remembrance: Space, Belonging and Politics of Memory in Eastern Europe (Budapest, 2012).

${ }^{13}$ Suffice it to say that integration has two basic components: there is the integration of international research techniques and results in Hungarian scholarship and the integration of Hungarian scholars into international networks of 
scholarship, as it is conducted in a more 'minor' European language, has been characterised by asymmetric relations to the outside world as well as by a high degree of openness for much longer than the past couple of decades: foreign influences, reception and adaptation have played centrally important roles throughout the modern era. To what extent the developments since 1989 are qualitatively or quantitatively novel and whether Hungarian scholarship has been integrated into larger networks, or rather, colonised from the outside with the help of local self-colonisers, remains to be explored in a more detached fashion. What is entirely clear is that the 1990s brought an intense wave of reception and internationalisation and the evolution of local memory studies are part and parcel of this larger restructuring and opening to international influences. ${ }^{14}$

Local traditions notwithstanding, this rapid and multifaceted wave was the primary trigger for the rise of Hungarian memory studies: their foundational texts, as we know the field today, originate from further west, above all from France and Germany. The local availability and impact of several of the most important paradigms in memory studies thus show the transnational embeddedness of the Hungarian field. On the other hand, the quantity of reception and the quality of adaptations vary, not to mention the fact that often there are serious time lags between the moment of original publication and Hungarian reactions - which sadly greatly limit the possibilities of Hungarian scholars to make serious international scholarly contributions.

We wish to illustrate this problem on the basis of what is arguably the most innovative Hungarian historical journal of the last decade, Korall. ${ }^{15}$ An internationally oriented journal launched in 2000, Korall is devoted to explorations in social history (where social history is understood, as is customary in Hungary, rather broadly, incorporating many inquiries that could easily be labeled new cultural

scholarship. The empirical question is what kind of balance between the two is needed and how symmetric the two sides have been.

${ }^{14}$ There was a significant debate on this problem in the middle of the 1990s. See the special issue of the journal Replika: Miklós Hadas (ed.), Colonization or Partnership? Eastern Europe and Western Social Sciences (Budapest, 1996), available at <http://www.c3.hu/scripta/scripta0/replika/honlap> [Accessed 18 May 2012].

${ }^{15}$ On Korall, see Anders Blomquist, "The Journal "Korall" and Social History in Hungary: Between International and National Contexts', East Central Europe, xxxiv-xxxv, 1-2 (2007-8), 113-38. 
history too). ${ }^{16}$ In 2010, Korall devoted its 41 st issue to 'History Writing and Memory'. The most commonly used international references in the altogether eight studies were to Jan Assmann (who was referenced in five of the studies), Paul Ricoeur (evoked in four), Maurice Halbwachs and Pierre Nora (both in three). ${ }^{17}$ We may say that they are understood as the core classics of the field and still constitute its 'mandatory references'. Therefore, it seems worthwhile to explore their presence in Hungary in greater detail: we shall cover the reception of their most important theories next and briefly address Hungarian traditions that could have been relied upon in the practice of memory studies after 1989 but that were often replaced by (rather than integrated into) the new approaches.

Before we do that, we ought to note that the recurrent references to these core classics makes it all the more conspicuous that only one of the studies in Korall, namely that written by Péter Apor, references leading contemporary scholars dealing with East Central Europe who published some of their essential works in memory studies, such as Ulf Brunnbauer, Maria Bucur, James Mark, Martin Sabrow, Stefan Troebst or Maria Todorova. ${ }^{18}$ This indicates that the recent reception wave did not manage to bridge the notorious time lag between international and local scholarly references. Pierre Nora and Jan Assmann arguably remain the two most influential theorists of social, cultural and historical memory in Hungary in spite of the fact that they both belong to the senior generation of scholars (Nora turns 81, Assmann 74 in 2012).

Nora and Assmann have both heavily drawn on perhaps the most important precursor of the field, Maurice Halbwachs (1877-1945). It thus seems entirely logical that there are plenty of references to Halbwachs in Hungary too and he often gets evoked as the 'founding father' of the field. While his name was made familiar to the Hungarian

${ }^{16}$ On Hungarian social history, see Zsombor Bódy and József Ö. Kovács (eds.), Bevezetés a társadalomtörténetbe (Budapest, 2006). On new cultural history, see Lynn Hunt, The New Cultural History (Studies on the History of Society and Culture, Berkeley, 1989); Peter Burke, What is Cultural History? (Cambridge, 2004).

${ }^{17}$ The Hungarian practicioners whose names appear in most studies are Gábor Gyáni (five), Zsolt K. Horváth (four) and Ferenc Erős (three).

${ }^{18}$ See Péter Apor, 'Hitelesség és hitetlenség: emlékezet, történelem és közelmúltfeldolgozás Kelet-Közép-Európában’, Korall, 41 (2010), 159-83. We shall return to the implications below. 
reader as early as 1971 when the conclusions of his Social Frameworks of Memory was made available in parts in an anthology of French sociology, the scholarly practice has arguably hardly changed since: there are all the 'mandatory' first citations but his ideas are only rarely earnestly integrated into research practices. ${ }^{19}$ There has not been any systematic effort to translate his works into Hungarian either: in fact the only newer translation is that of his study on collective memory and time published (once again) in a reader covering major sociological approaches of the twentieth century. ${ }^{20}$ The one and only empirical memory study of Halbwachs discussing the 'legendary topography' of the Holy Land remains yet to be fully translated. ${ }^{21}$

The thoughts of Paul Ricoeur on time, history and memory are rarely reflected in mainstream Hungarian memory studies, even though many of his works (particularly those in literary theory) are available and recurrently cited. ${ }^{22}$ It seems to us that his theory on narrative identity remains insufficiently known and is often misrepresented. This is all the more surprising since one of the leading Hungarian philosophers, László Tengelyi, who serves as professor at the University of Wuppertal, has published excellent philosophical discussions on narrative theories and life stories, including substantial discussions of Ricoeur's oeuvre. ${ }^{23}$ Without meaning to focus on deficits, we ought to note that Ricoeur's major work La mémoire, l'histoire, l'oubli did not exert a notable impact until now either. ${ }^{24}$

${ }^{19}$ Maurice Halbwachs, 'Az emlékezet társadalmi keretei', in Zsuzsa Ferge (ed.), A francia szociológia (Budapest, 1971), 124-31.

${ }^{20}$ Maurice Halbwachs, 'A kollektív emlékezet és az idő', in Gábor Felkai, Dénes Némedi and Péter Somlai (eds.), Szociológiai irányzatok a XX. század elejéig (Budapest, 2000), 403-32.

${ }^{21}$ Maurice Halbwachs, 'A Szentföld legendás topográfiája', Magyar Lettre Internationale, 37 (2000), 45-8.

${ }^{22}$ See the anthology of his different writings entitled 'Selected literary theoretic writings': Paul Ricoeur, Válogatott irodalomelméleti tanulmányok (Budapest, 1999).

${ }^{23}$ László Tengelyi, Élettörténet és sorsesemény (Budapest, 1998).

${ }^{24}$ Only his reflections on the conception of this book are available in Hungarian but (one might wryly note: characteristically) even that was translated from German. Paul Ricoeur, 'Emlékezet - felejtés - történelem', in Beáta Thomka (ed.), Narratívák 3. A kultúra narratívái (Budapest, 1999). Ricoeur’s work was extensively reviewed by Gábor Gelléri, 'Az emlékezet-fenomenológiától az emlékezet-politikáig. Paul Ricoeur új könyvéről', Korall, 5-6 (2001), 253-62. 
The reception of Pierre Nora and his approach to memory followed a somewhat unusual path: its beginnings namely long preceded the translation of his works. The overall enterprise of Les lieux de mémoire and its key concepts were more earnestly discussed first in relation to the exhibition 'Hungarians between "East" and "West". National symbols and Legends' held at the Museum of Ethnography in Budapest in 1994. A paper related to this exhibition, written by Tamás Hofer and titled 'Can Hungarian realms of memory be exhibited?', opened the debate on the possible adaptation of the French project to Hungary. In this seminal contribution, Hofer argued that the exhibition in question was inspired by Nora's endeavours insofar as, instead of reproducing one or another variant of the progressive narrative of 'national history' all so dominant until then, it juxtaposed national themes and symbols and tried to reveal their historical and context-dependent nature. ${ }^{25}$

The key moment in the Hungarian reception of Pierre Nora was the translation of the introductory article of Les lieux de mémoire in 1999. This translation appeared in Aetas, a leading history journal based in Szeged. It was accompanied by an overview of the "landscape of French memory research' written by the translator, Zsolt K. Horváth, himself a leading practitioner of memory studies. ${ }^{26}$ These two related publications greatly facilitated the spread of the conceptual apparatus associated with the realm of memory approach but it practically remained the sole reference point until a volume of Les lieux de mémoire essays finally appeared in 2009. ${ }^{27}$ One unfortunate consequence of this partial and delayed reception was that various criticisms, including self-critical reflections by Nora himself on the limitations of his project, did not enter the Hungarian discussion on time. ${ }^{28}$

${ }^{25}$ Tamás Hofer, 'Kiállíthatók-e a magyar “emlékezet helyei”', Buksz, vi, 4 (1994), 465-70.

${ }^{26}$ See the analysis of the House of Terror in Budapest: Zsófia Frazon, Zsolt K. Horváth, 'A megsértett Magyarország. A Terror Háza mint tárgybemutatás, emlékmü és politikai rítus', Regio, xiii, 4 (2002), 303-47; Zsolt K. Horváth, 'The Redistribution of the Memory of Socialism: Identity Formations of the "Survivors" in Hungary after 1989', in Péter Apor and Oksana Sarkisova (eds.), Past for the Eyes: East European Representations of Communism in Cinema and Museums after 1989 (New York and Budapest, 2008), 247-73.

${ }^{27}$ Pierre Nora, Emlékezet és történelem között: válogatott tanulmányok (Budapest, 2009).

${ }^{28}$ For his self-critical reflections, see idem, 'L'ère de la commémoration', in idem (ed.), Les lieux de mémoire, pt. iii: Les France, vol. iii: De l'archive à l'emblème 
Controversial questions such as the relations between memory politics and history writing and various epistemological and ethical considerations are nearly completely absent from local discussions.

The seductive potential of the realms of memory approach seems to lie, above all, in its promise that a coherent scholarly interpretation of national memory is possible. ${ }^{29} \mathrm{~A}$ recent research project at the University of Debrecen drawing on European funding may illustrate this trend: the project, led by Pál Varga, was titled 'Hungarian Realms of Memory' (Magyar emlékezethelyek) and its declared aim was to 'employ the concept of Pierre Nora, lieux de mémoire, in the Hungarian context to reinterpret the operational mechanisms of Hungarian cultural memory'. ${ }^{30}$ Somewhat oddly, no others than Aleida and Jan Assmann were invited to deliver the keynote addresses at the largest scholarly conference connected to this Hungarian project that was held in November 2011. ${ }^{31}$ This simple fact shows that, while differences in international orientation persist and remain important, the Hungarian research field does not seem to be fragmented according to followers of various national traditions: French and German influences, among others, coexist and the resulting local projects are rather eclectic in orientation, conception and design.

Next to the abovementioned French practitioners, Jan Assmann has also been a household name in Hungary especially since the appearance of the translation of his major work on cultural memory in $1999 .{ }^{32}$ The reception of his theory on the functioning of cultural and communicative memory is similar to that of the 'realm of memory' in at least two important respects. First, his concepts enjoy great

(Paris, 1993); idem, 'Recent History and the New Dangers of Politicization' (2011), available at <http://www.eurozine.com/pdf/2011-11-24-nora-en.pdf> [Accessed 18 May 2012].

${ }^{29}$ A critical interpretation of the uses of national traditions focused on celebrations can be found in Ákos Kovács, A kitalált hagyomány (Bratislava, 2006).

${ }^{30}$ See < http://kutatoegyetem.unideb.hu/portal/node/37> [Accessed 18 May 2012]. Former nominally Noraian projects include János Potó, Az emlékeztetés helyei. Emlékmüvek és politika (Budapest, 2003).

${ }^{31}$ See <http://deba.unideb.hu/hirek/LOCI_MEMORIAE_HUNGARICAE_ program.pdf $>$ [Accessed 18 May 2012].

32 Jan Assmann, Das kulturelle Gedächtnis. Schrift, Erinnerung und politische Identität in frühen Hochkulturen (Munich, 1992), Hungarian edn: A kulturális emlékezet. Irás, emlékezés és politikai identitás a korai magaskultúrákban, trans. Zoltán Hidas (Budapest, 1999). 
popularity and are recurrently used in research projects on 'collective identity' in particular - whether on the national or subnational level. The other is the multidisciplinary nature of the studies employing this toolkit: Assmann is an important reference point not only in historical studies but also in sociological and cultural anthropological researches as well as in literary studies (where research projects on literary cults draw on him in particular). ${ }^{33}$

This observation has a more general applicability to the overall disciplinary profile of memory research. Beyond the discipline of history, the most important fields concerned with the problem of memory are sociology, ethnology and the related (more newly emerging) field of cultural anthropology. ${ }^{34}$ While oral historians seem more willing than other practitioners of historical studies to address the epistemological, methodological and political-ethical problems related to accessing and representing the past, it seems to us justified to argue that Hungarian history writing lacks vivid debates on the consequences of the linguistic turn, the public functions of history or more recent developments in comparative genocide studies that innovatively deal with victim testimonies. ${ }^{35}$

The relatively weak anchoring of memory studies in the discipline of history certainly has multiple causes. One of these is the gradual pluralisation of Hungarian historiography prior to 1989 and its strong continuity after 1989, both in terms of themes and personnel. At the same time, as identified by Balázs Trencsényi and Péter Apor in their 'Fine-tuning the Polyphonic Past: Hungarian Historical Writing in the 1990s', the current middle generation acquired leading positions after 1989. Members of this scholarly generation were namely chiefly

${ }^{33}$ See, e.g., the compilation of conference papers edited by scholars working at the Institute for Ethnic and National Minority Studies of the Hungarian Academy of Sciences on Hungarian historical consciousness and cultural memory in national and minority situations: Richárd Papp and László Szarka (eds.), Bennünk éló múltjaink. Történelmi tudat - kulturális emlékezet (Senta, 2008).

${ }^{34}$ There is also a (cognitive) psychological branch of researching memory in Hungary, related to the approach of narrative psychology and to the social representation theory of Serge Moscovici. Methodologically these studies are often quantitative. See, e.g., the thematic issue of the journal Magyar tudomány, 2003, no. 1. Especially the contributions of János László, Ferenc Pataki, Bea Ehmann. See also the publications of Anikó Kónya on biographic memory.

${ }^{35}$ The work of Róbert Braun remained relatively isolated, see idem, Holocaust, elbeszélés, történelem (Budapest, 1995). 
responsible for what is probably the most significant development in Hungarian historiography: the rise to prominence of a peculiarly inclusive variant of social history. ${ }^{36}$

One might be tempted to argue that the institutional embeddedness and relative inclusivity of Hungarian social history partly fostered but to some extent might also have hindered the cultural turn of Hungarian historiography. More concretely, the prolonged belief that social history is the most innovative branch of historiography has probably helped disable a larger-scale historiographical reorganisation over the past decade. This could have happened, among others, through research projects that tackle questions of history and memory, as it did happen elsewhere, or seems to be happening right now (Poland may be one of the most relevant examples for the latter case). ${ }^{37}$

To provide merely one striking illustration of the pattern: the Hajnal István Kör is an organisation of historians founded in 1989 (though its precursor started its activities in 1986) and easily one of the most important agents of historiographical innovation. Its explicit focus is social history and its annual conferences and conference volumes recurrently make substantial contributions to Hungarian historical discussions. Without ever naming memory studies as such as its main topic, the Hajnal István Kör devoted four annual conferences to related cultural themes already, including: the history of mentalities (1998); the themes of celebrations, the everyday and memory (2000); individual time and historical time (2003); and, the cultural turn in history writing (2006). In short, primarily social-historically-oriented projects have partly incorporated memory research into their agendas. On the other hand, Hungarian memory studies cannot claim to have launched major initiatives (such as the impressive new Poland-based international project 'Genealogies of Memory') or established its own centres yet.

If we had to mention one scholar whose work symbolises this rather gradual shift towards cultural history and the increased

${ }^{36}$ Balázs Trencsényi and Péter Apor, 'Fine-tuning the Polyphonic Past: Hungarian Historical Writing in the 1990s', in Sorin Antohi, Balázs Trencsényi and Péter Apor (eds.), Narratives Unbound. Historical Studies in Post-Communist Eastern Europe (Budapest and New York, 2007), 9.

37 This cultural turn can be observed in various shapes in the trend-setting historiographies of the world, the Anglo-Saxon, the French and the German. See Doris Bachmann-Medick, Cultural Turns. Neuorientierungen in den Kulturwissenschaften (Reinbek, 2006). 
recognition of the importance of memory studies, it would have to be Gábor Gyáni. Not only is he a leading social historian of the middle generation with in-depth researches on the modern urban experience, but he also disseminates knowledge and provides interpretations of current international developments in historical writing with particular emphases on the epistemological, methodological and political questions central to the historical profession and the social function of the historian. Gyáni is also known for his mostly critical reflections on the international (in)compatibility and (lack of) recognition of Hungarian scholars. ${ }^{38}$ Beyond all this, he published several foundational studies where he discusses the achievements and possibilities of memory research. ${ }^{39}$

In spite of such calls by some leading social historians, memory research seems to be a more integral part of the disciplines of sociology, ethnology and cultural anthropology than of local historiography. Moreover, the former two are fields where considerable continuity between the pre- and post-1989 scholarly works on memory can be observed. The biographic approach, for instance, was well known and often applied by scholars conducting qualitative interviews already in the 1980s - although, as noted above, scholars back then did not analyse biographic memory as a 'narrative construct'. ${ }^{40}$ Life stories were rather viewed simultaneously as sources about objective reality and products of meaning attribution to be studied in their own right. Nevertheless, the first substantial theoretical considerations on how life stories ought to be researched and self-narration studied appeared already in $1988 .{ }^{41}$

${ }^{38}$ In English see, e.g., Gábor Gyáni, György Kövér and Tibor Valuch (eds.), Social History of Hungary from the Reform Era to the End of the Twentieth Century (Social Science Monographs, Boulder, 2004); Gábor Gyáni, Women as Domestic Servants: The Case of Budapest, 1890-1940 (New York, 1989); idem, Identity and Urban Experience: Fin-de-Siécle Budapest (New York, 2004).

${ }^{39}$ See, especially Gábor Gyáni, Emlékezés, emlékezet és a történelem elbeszélése (Budapest, 2000).

${ }^{40}$ See the extensive research project of sociologist István Kemény on poverty and on the Roma population in 1970s: István Kemény, 'A magyarországi cigányok helyzete', in idem et al., Beszámoló a magyarországi cigányok helyzetével foglalkozó 1971-ben végzett kutatásról (Budapest, 1976). Another good example is Judit $\mathrm{H}$. Sas's research among young workers of the Orion factory in the first half of the 1980s, eadem, Szubjektív történelem 1980-1994 (Budapest, 1995).

${ }^{41}$ Péter Niedermüller, 'Élettörténet és életrajzi elbeszélés', Ethnographia, xcix, 3/4 (1988), 376-89; Tamás Hofer and idem (eds.), Life History as a Cultural 
The rich local traditions of life story analysis are by no means entirely lost and forgotten but they have gradually declined. This can be ascertained also by looking at the story of the formerly highly influential tradition of sociography, a problem-oriented semi-literary description of society addressed at the wider reading public that combines various methods of collecting and presenting research material. ${ }^{42}$ Internationalisation has been centrally important in life story researches too: the strongest theoretical and methodological influence on researches conducted today seems to be the German school of hermeneutic case reconstruction, an approach originally developed by researchers such as Wolfram Fischer-Rosenthal and Gabriele Rosenthal. ${ }^{43}$

IV

CENTRAL THEMES AND MAJOR RESULTS OF HUNGARIAN MEMORY STUDIES

The 1956 revolution

Due especially to the former institutional prestige and sustained scholarly efforts of the (recently abolished) Institute for the History of the 1956 Hungarian Revolution, the revolution of 1956 has loomed very large, so much so that attention devoted to it nearly threatened to overshadow other historical issues. The Oral History Archive (OHA) of the Institute was officially established in 1985, although interview collection informally began as early as 1981 with the aim of documenting the 'real history' of the Revolution against official attempts to silence the memories of its participants and hinder their intergenerational transmission. ${ }^{44}$ After 1989 , the research focus of

Construction/Performance: 3rd American-Hungarian Folklore Conference: Papers (Budapest, 1988).

42 The revival of Hungarian sociography in the post-war period dates back to 1970s when the first volume in the series 'Magyarország felfedezése' [Discovering Hungary] appeared. The series still continues (see <www.magyarorszagfelfedezese. hu $>$ [Accessed 18 May 2012]) but can count on very limited amount of interest.

${ }^{43}$ Éva Kovács and Júlia Vajda are the most important practitioners of this approach who were partly trained in Göttingen at the beginning of the 1990s.

${ }^{44}$ On the oral history archives in Hungary, especially on OHA and its antecedents, see András Lénárt, “Történetgyújtés” - Oral history archívumok Magyarországon’, Aetas, xxii, 2 (2007), 5-30. 
the Institute gradually broadened from the reconstruction of the Revolution to the investigation of the communist period in Hungary as a whole, yet with continued emphases on the history and historical memory of 1956. The major purpose of life stories seems not to have changed substantially: it seems to have remained the provision of important and otherwise inaccessible but essentially supplementary knowledge on history and the enrichment of our sense of history with a feel for the subjective experiences of historical agents. The majority of the OHA's publications are indeed interview compilations. More problem-oriented and analytically focused studies are only a significant minority. ${ }^{45}$

A characteristic oral history project of this institute is that of Zsuzsanna Körösi and Adrienne Molnár exploring the lives of children of post-1956 reprisal victims (the parents in question were either executed or imprisoned).$^{46}$ Excerpts from altogether forty-two oral history interviews originally conducted between 1994 and 1998 are presented here in thematic and chronological order and are recurrently 'interrupted' by the comments and interpretations of the authors. The book provides a clear answer to the question of generalisation often raised in relation to oral history research material. On the one hand, the interviewees are treated as members of a social group meant to function as a kind of seismograph and be able to reveal the relation of society both to the state and to the Revolution: the life of this social group is seen as 'close' to the everyday life of the majority, yet (or rather because it is) directly and profoundly affected by the Revolution. On the other hand, the book focuses on questions of traumatisation, stigmatisation and familial socialisation, and is meant to explore the 'silenced history' of the Kádár period.

${ }^{45}$ The book dealing with the memory of the 1960s, in which excerpts from OHA interviews are published in a thematic structure provides a good example. Adrienne Molnár (ed.), A "hatvanas évek" emlékezete: az Oral History archívum gyüjteményéból (Budapest, 2004). E.g. a recent research project entitled 'The Other Hungary - Critical and Opposition Movements and Groups in Hungary's Kádár Period' which relies on both oral history and written archival sources. See its details at <http://www.rev.hu/portal/page/portal/rev/projektek/masik_magyar.> [Accessed 18 May 2012].

${ }^{46}$ Zsuzsanna Körösi and Adrienne Molnár, Carrying a Secret in My Heart...: Children of the Victims of the Reprisal after the Hungarian Revolution in 1956: An Oral History (Budapest and New York, 2003). First published in Hungarian in 2000 under the title Titokkal a lelkemben éltem. 
The attitude of the researchers to their work seems to diverge from what is conventionally expected from historians:

We have not examined the factuality and truth value - that is, the authenticity - of what we have heard. Neither do we have the right, nor do we consider it to be our task to correct them. ${ }^{47}$

This introductory declaration of the book reveals the intention to put exclusive emphasis on memory, which is in turn equated with the subjective interpretation and experience of historical events. The credibility of the speakers and the taken-for-granted authenticity of their witnessing are meant to guarantee the truth value of the volume.

\section{The Kádár era (1956-1989)}

Another important topic of memory research in the past two decades with evident links to the history of the 1956 revolution is the period between 1956 and 1989, usually named after the General Secretary of the Hungarian Socialist Workers' Party, János Kádár (1956-88). Hungarian historical research on this period takes place in a context where putting the blame on the 'continuation of the past' has proved to be a popular way to 'explain' present social problems - and not only in post-communist Hungary. According to this interpretation, the main obstacle to the 'completion of the transition' remains 'the survival of the mentality' of the Kádár period. This pattern of dichotomising progressivist thinking could frequently be detected in political discourses but was present in the social sciences and, to a lesser extent, in the humanities as well. Another increasingly popular trend of relating to the Kádár era prefers to focus on the victims and perpetrators of the dictatorship and emphasises the need to confront the crimes of the past: it ambitions a more widespread recognition of past suffering.

In our view, both of these mainstream trends tend to exclude in-depth reflections on how memories function and provide no sustained analyses of their contents. Agents of the first trend typically do this by simply assigning what survives from the past to the negatively charged category of 'nostalgia', instead of viewing them as products

${ }^{47}$ Eaedem, Carrying a secret, 9. 
of dynamic social processes in the contemporary era. Our impression is that local agents of the second trend, 'confrontation' with the past, tend to maintain that memories can provide direct access to the harsh realities of the past. Thus, questioning their way of emergence, exact content and social function in a more critical and detached manned remain a rarity in these exercises.

It is against this background that the specificity of the two memory researches on the Kádár era we wish to discuss next can be grasped. The oral history research of Eszter Zsófia Tóth discusses everyday life in the Hungarian People's Republic and focuses on the way women who formerly worked in factories experienced it at the time and remember it now. ${ }^{48}$ This microhistorical study is based on oral history interviews made with members of a former worker brigade in the years 1999 to 2004 . Her research design enabled Tóth to investigate the tensions unfolding in the interviews. One such tension was inherent to the limited actual possibilities of members of an officially privileged group (female workers) in the past. Another tension arises from the contrast between the past acknowledgement and the present material and symbolic degradation of workers: in somewhat simplified terms, we may say that they went from being the 'progressive ruling class' to being seen as accomplices of a dictatorship. The book discusses several themes that are addressed in the life story interviews such as migration to urban areas, working class identity, consumption, or gender roles. Although Tóth explicitly asserts that life stories ought to be considered as narrative constructs about the past, narrativistic methods did not seem to play any notable role in the making of her interviews, nor does she apply narrative theories in her analysis. In the mosaic-like arrangement of the book interview excerpts tend to serve as mere illustrations of the author's claims.

Sociologist Éva Kovács led a methodologically sounder and analytically more thorough research project between 2002 and $2005 .{ }^{49}$ Titled 'The Social Memory of the Kádár Era', this project employed the narrative method particularly of Gabriele Rosenthal to conduct nearly one hundred interviews. It aimed to access 'life story memory' of the

${ }^{48}$ Eszter Zsófia Tóth, "Puszi Kádár Jánosnak". Munkásnók élete a Kádár-korszakban mikrotörténeti megközelitésben (Budapest, 2007).

${ }^{49}$ Éva Kovács (ed.), Tükörszilánkok. Kádár-korszakok a személyes emlékezetben (Budapest, 2008). 
socialist period, trying to comprehend how this particular historical period is constructed nowadays as part of life story narratives. In other words, the primary focus of the research project was on the memory strategies of the present and how contemporary identity politics related to the ways the state socialist era was remembered. ${ }^{50}$ In accordance with this ambition, the interview subjects were selected according to their belonging to groups with special significance in the present, not in the past. The starting assumption was merely that the dissolution of the system 'might have been a turning point' in the life of the interviewees.

The interviewees were selected based on their belonging to ethnic and social categories whose everyday and institutional usage got transformed in the course of the regime change. In fact, none of the selected categories existed publicly in their present form before 1989. On the one hand, individuals currently belonging to the Jewish, Roma, German, Slovak and Serb/Croat categories got to be interviewed. On the other hand, people with noble family origins and without shelter were also involved in the project. The life stories of former emigrants (so called 'dissidents' of the socialist system) who left the country after 1956 but returned after 1989 offered an opportunity to compare the role of 'lived' as opposed to 'imagined' experiences of the examined historical period. The published volume included another 'control group': interviews were conducted with members of the former and formerly officially supported category of 'cadres' as well.

The rich opportunities inherent in this research design have unfortunately not been fully exploited. The different identity political strategies are not reconstructed within a consistent theoretical frame. Thus, they could not be systematically compared. The major differences between the relevant groups are not sufficiently reflected upon either. Although the volume does not offer a synthetic vision, several of the individual studies substantially contribute to the understanding of the socialist past in Hungary and show the innovative potential of memory research.

50 This contrast between Kovács's and Tóth's research projects arguably reflects the contrast between the presentism of social science and the focus on the past of historians: while for the former the present has clear epistemological priority, the present is rather seen as the product of the past by the latter. 
The project Emlékpontok undoubtedly qualifies as the largest recent Hungarian project on the memory of the state socialist past. Conducted between 2009 and 2011 and directed by the organisation responsible for the maintenance of the (also internationally much discussed and debated) House of Terror Museum, this project had locally unmatched financial resources at its disposal. The outcome of it may be called somewhat unusual as well: through the active participation of sixty-nine secondary schools, around a thousand pupils were involved in carrying out the overwhelming amount of altogether approximately 3,200 audiovisual interviews with elderly people who lived through the years between 1945 and 1989. The declared central aims of the enterprise were to 'preserve the common social memory' and introduce 'historical interviews' into secondary education.

Taking into account the size of the sample and the method of collection, it comes as no surprise that the methodological quality of the interviews is highly varied. In accordance, the professional reception of the project was at best ambivalent and at times sharply critical. Even though the video collection is made available online, to our knowledge it has not been analysed in scholarly works yet (nor is there sufficient public information on the frequency and ways of its use in public education). All in all, the Emlékpontok project should be located somewhere at the edge of the scholarly realm: it has been an intervention into the way Hungarian people remember and communicate about the past as much as (if not more than) a sound scholarly project.

\section{Memory and identity of minorities}

Several important research projects on the memory and identity of minorities were conducted well before the collapse of the communist regime. The study of Jewish identity began already in the early 1980s though at first in a partly informal way. ${ }^{51}$ A major post-1989 study we wish to discuss here is the one conducted by sociologists Éva Kovács and Júlia Vajda. In 1992 and 1993, Kovács and Vajda collected life story accounts in families where at least one of the children attended one of the several newly established Jewish schools. Between

${ }^{51}$ See Ferenc Erős, András Kovács and Katalin Lévai, “"Hogyan jöttem rá, hogy zsidó vagyok?” Interjúk', Medvetánc, 2-3 (1985), 129-44. 
1998 and 2000, they conducted additional interviews with individuals who identified themselves as Jews.

The two scholars were primarily interested in the ways individuals and families constructed their Jewish identities after decades of 'tabooisation' ended, the Hungarian public sphere was heavily restructured and newly started to explicitly address Jewish matters. Psychological and psychoanalytical tools play an important role in their analysis, in accordance with the popularity of such theories in researches on Jewish topics both inside and outside Hungary. ${ }^{52}$ Kovács and Vajda eventually published their results in book format in 2002, in which two introductions, an analytical and a social historical one, were followed by eleven largely independent case studies.

Roma memories are often discussed in the context of the history of persecution too. While selected recollections of Roma people were published already before $1989,{ }^{53}$ the post-communist liberation and expansion of the memory political field has not yet resulted in the emergence of proper scholarly studies on the memory of the persecution and genocide against the Roma. No more than few compilations of life story accounts have appeared until now. ${ }^{54}$

The study of the German minority in Hungary is also influenced by the relatively new but already mainstream tendency to focus on historical cataclysms. Ágnes Tóth, historian and director of Institute for Ethnic and National Minority Studies of the Hungarian Academy of Sciences, conducted a research on the memory of Germans who had been 'resettled' after the Second World War but had chosen to return to Hungary. ${ }^{55}$

${ }^{52}$ An interesting branch of Hungarian memory studies is the one focusing on the Hungarian history and cultural memory of psychoanalysis, especially on the role and work of Sándor Ferenczi and the Budapest School. See, e.g., Ferenc Erős, Pszichoanalizis és kulturális emlékezet (Budapest, 2010). Psychologists have also made substantial contributions to the discussions, see the works of, i.a., Csaba Pléh, János László and Anikó Kónya.

${ }^{53}$ See, e.g., Zsolt Csalog, Kilenc cigány (Budapest, 1976).

${ }^{54}$ See Gábor Bernáth (ed.), Porrajmos: e Roma seron, kon perdal zhuvinde/Roma Holocaust túlélók emlékeznek/Recollections of Roma Holocaust Survivers [sic!] (Budapest, 2000); Katalin Katz, Visszafojtott emlékezet. A magyarországi romák holokauszttörténetéhez (Budapest, 2005); Ágnes Daróczi and János Bársony (eds.), Pharrajimos. The Fate of the Roma During the Holocaust, trans. Gábor Komáromy (Budapest, 2008; orig. edn 2004).

${ }_{55}$ Ágnes Tóth, Hazatértek. A németországi kitelepitésböl visszatért magyarországi németek megpróbáltatásainak emlékezete (Budapest, 2008), or cf. its German 
The ambition of Tóth was to reconstruct their motivations to return and their various forms of attachments to Hungarian and German society. Besides thematically structured oral history interviews, all forty-six interviewees were asked to fill in a questionnaire too that led to the establishment of a database. The analysis of the interviews is mostly quantitative and excerpts from the life story narrations also often seem to have rather illustrative functions. However, the book includes nineteen interviews as a sort of appendix.

\section{$\mathrm{V}$ \\ BETWEEN TRANSNATIONAL EMBEDDEDNESS AND RELATIVE ISOLATION}

While until now we have looked at how and to what extent Hungarian memory studies has been integrated into the national scholarly mainstream, in this last part of our paper we turn to the question of its international integration. We ought to note that in recent years the international standing of Hungarian scholarship and, more particularly, of historiography has been the subject of renewed polemic. These debates may be seen as part of a recent wave of critically confronting the actual level of Europeanisation after two decades when various narratives of Europeanisation provided an important source of political legitimation and images of a better future.

A major incentive to such historiographical debates was provided by Gábor Gyáni who articulated thoughtful but rather provocative theses on the relatively peripheral position of Hungarian researches on the Holocaust. ${ }^{56}$ While acknowledging that the topic receives much more attention than before, Gyáni pointed to the rather provincial horizon of local researchers, their lack of familiarity with relevant contemporary scholarly developments and their seemingly widespread ignorance of theoretical and methodological dilemmas. One of his major complaints concerned the exceptionally low level of the international reception of Hungarian Holocaust scholarship: he argued that

translation, Rückkehr nach Ungarn 1946-1950: Erlebnisberichte ungarndeutscher Vertriebener (Munich, 2012).

${ }^{56}$ Gábor Gyáni, 'Helyünk a holokauszt történetírásában', Kommentár (2008), no. 3, pp. 13-14. Gyáni recently published on the international embededdness of Hungarian historiography more generally too: idem, 'A hazai történetírás nemzetközi beágyazottsága. Egykor és most', Aetas, xxv, 4 (2010), 15-27. 
it was way below what the scale and importance of the Hungarian Holocaust would merit. ${ }^{57}$ These theses have become the subject of much controversy and were most extensively contested by László Karsai, one of the leading Hungarian historians of the Holocaust. ${ }^{58}$

On the topic of the Holocaust but more directly related to memory studies, Éva Kovács, András Lénárt and Anna Lujza Szász recently published an overview of the archives of Hungarian Holocaust witnessing and their current level of digitalisation. Offering a substantial coverage of the relevant oral history projects of the past decades, their specificities and achievements, the three authors critically remarked that researchers have made extremely limited use of these abundant personal and subjective sources. The two most outstanding exceptions they mentioned were the recent works of Tim Cole and Eleonore Lappin-Eppel - both of whom are not natives of Hungary. ${ }^{59}$

While the participation of Hungarian scholars and the relative proportion of Hungarian topics in international discussions of memory both leave something to be desired, we see the partial divergence of these two issues as a noteworthy recent development. The limited success of Hungarian memory research at becoming part of the national mainstream at a time of an international memory research

${ }^{57}$ Let us note that some more recent developments contradict this theory of underrepresentation: new encompassing projects devote proportiate attention to Hungary. The Hungarian Holocaust will receive a separate volume among the sixteen volumes of the Editionsprojekt Judenverfolgung 1933-1945. (This volume should be vol. 15 to be edited by Regina Fritz.) The series 'Documenting Life and Destruction. Holocaust Sources in Context', edited by Jürgen Matthäus at the United States Holocaust Memorial Museum will include a stand-alone volume on Hungary too, to be edited by Gábor Kádár and László Csősz.

${ }^{58}$ See László Karsai, 'A magyar holokauszt-történetírásról. Válasz Ablonczy Balázsnak, Csíki Tamásnak, Gyáni Gábornak és Novák Attilának', Kommentár (2008), no. 6, pp. 91-104. Unfortunately, the debate has deteriorated rather quickly. Thus, in spite of prolonged exchanges, no fully satisfying answers have emerged to the crucial questions that the original contribution of Gyáni raised: first, what are the current international trends and what are their theoretical-methodological foundations?; and, second, how up-to-date are Hungarian scholars and how relevant is their work internationally?

${ }^{59}$ Éva Kovács, András Lénárd and Anna-Lujza Szász, 'A magyar holokauszt személyes történetének digitális gyüjteményei', Buksz, xxiii, 4 (2011), 350. See Tim Cole, Traces of the Holocaust: Journeying In and Out of the Ghettos (London, 2011); Eleonore Lappin-Eppel, Ungarisch-Jüdische Zwangsarbeiter und Zwangsarbeiterinnen in Österreich 1944/45 (Berlin, 2010). 
boom namely means that Hungarian topics are increasingly often studied by non-Hungarian scholars.

A leading example here is James Mark whose important monograph The Unfinished Revolution is primarily in 'cultures of historical reinvention': he explores in detail how the need to reject communism was ever more frequently, not to mention aggressively, invoked. Mark essentially provides a regional narrative about Central and Eastern Europe but draws heavily on Hungary where he conducted most of his rich oral history interviews. ${ }^{60}$ Similarly characteristic is the fact that the first monographic treatment of the memory of the Holocaust in Hungary will be based on the dissertation Regina Fritz defended at the University of Vienna and shall appear in German later this year. ${ }^{61}$ As far as we know, no translations of these works into Hungarian are being planned yet.

It is no mean challenge to try to classify and briefly summarise the work of historian István Rév, director of the Open Society Archive in Budapest. His volume of studies Retroactive Justice is quite special in several ways, only one of which is that it only appeared in English: Rév is one of several locally active scholars who seem to be involved in international scholarly discussions as much as in local ones. ${ }^{62}$ One of the emphases of Rév is on the political and symbolic significance of present day practices including reburials, renamings, rehabilitations and exhibitions. His non-linear and non-chronological historical investigations are clearly not restricted to post-communist times: the making and remaking of history and memory in the present is explored here as a part of long-term historical processes, legacies, political manipulations and popular beliefs while several stories revolve primarily around traces of the 1956 revolution.

The overall aim of Rév appears to be the study of the repeated revolutionary turns in twentieth-century Hungary, beginning with the political changes in 1918. Through telling examples, he ambitions to show how multiple turns produced ever newer versions of the past: 'At any given moment history became foreshortened, retrospectively

${ }^{60}$ Mark, The Unfinished Revolution.

${ }^{61}$ Regina Fritz, Nach Krieg und Judenmord. Ungarns Geschichtspolitik seit 1944 (Göttingen, 2012).

${ }^{62}$ István Rév, Retroactive Justice: Prehistory of Post-communism (Stanford, CA, 2005). 
foreseen in a different way'. ${ }^{63}$ Each chapter of his book thus presents a story of remaking as well as a story of undoing by remaking: the dead body, the name of the dead, the holy days, the criminal, the political transition. In some sense, Retroactive Justice is the first Hungarian book (even if written in English) that shows an attractive, even if slightly idiosyncratic way to integrate the history and memory of the twentieth century and reveal intriguing aspects of their deeply intertwined nature.

Next to scholars working on Hungary in various places and diverse languages other than Hungarian, there are those who publish extensively both in Hungarian and in other tongues. Péter Apor and Zsolt K. Horváth provide perhaps the best illustrations of the relatively young local-international scholars with substantial publications about issues of memory. A graduate of the European University Institute in Florence, Apor will soon publish his first Hungarian-language monograph on communist era representations of history in Hungary but has also been actively involved in international projects, most recently, with an important study in the volume A European Memory? ${ }^{34}$ Horvatth is a graduate of both ELTE Budapest and EHESS in Paris, who has published on questions of memory in multiple languages other than Hungarian, primarily in French. While the scholarly works of such younger local-international scholars are of high quality and certainly match international standards, it would be an exaggeration to say that they belong to the international scholarly elite: they have not published in leading international journals of the memory research field, nor have they led larger international research projects yet. Still, they provide the best examples of how international expertise and involvement and local presence can be combined. At the same time, their (in our view rather limited) local impact can tell us much about the openness and receptivity of the Hungarian scholarly community.

A crucial additional question related to the internationalisation of Hungarian scholarship concerns the evolution of regional contacts and cooperation. Here, relations to neighbouring countries such as Austria,

${ }^{63}$ Ibidem, 7.

${ }^{64}$ See Péter Apor, 'Eurocommunism: Commemorating Communism in Contemporary Eastern Europe', in Małgorzata Pakier and Bo Stråth (eds.), A European Memory? Contested Histories and Politics of Remembrance (Studies in Contemporary European History, 6, Oxford, 2010), 233-46. 
Slovakia and Romania seem particularly relevant for historical reasons, although, sadly, they are still rather weakly developed. No larger bilateral projects in memory studies have been conducted yet. ${ }^{65}$ This is partly due to structural reasons: while major countries are increasingly included in European canons they largely jointly create and reproduce, smaller countries seem to have a harder time finding a relevant frame for their cooperation: while Europe provided an obvious frame for German-French and, more newly, for German-Polish reconciliation and the opportunity to define Europe anew was attractive enough (even though in the former case historiographical cooperation has remained surprisingly limited), Hungarians seem to have a hard time redefining anything important in their own image with their potential partners. Moreover, as shown above, extra-regional contacts and influences remain more attractive and decisive to most scholars than intra-regional ones. Besides the relative isolation Hungarian scholars find themselves after decades of nominal Europeanisation, there has namely also been a massive state-endorsed renationalisation of historical memory in recent years - the full impact of which is still be to seen. In our view the aforementioned structural problems with embedding Hungarian memory studies in larger, regional or continental units is directly correlated with the increased recent focus on national and sometimes downright nationalistic memory.

Poland might be the best counter-example to illustrate the relative insularity of Hungary as the gap has spectacularly grown between these two countries in particular. While both Polish and Hungarian historiographies used to be characterised by their relative openness and the availability of international contacts before 1989, especially the interest of Germany in reconciliation (historiographical and otherwise) with its major eastern neighbour, Poland has resulted in numerous collaborative projects without any parallel in the case of Hungary ${ }^{66}$ In spite of the near complete absence of such collaborative projects, may they be German-Hungarian or other bilateral or

${ }^{65}$ The largest relevant research project has been Matthias Weber et al. (eds.), Erinnerungsorte in Ostmitteleuropa. Erfahrungen der Vergangenheit und Perspektiven (Munich, 2011).

${ }^{66}$ Now see, above all, the project 'Deutsch-polnische Erinnerungsorte/Polsko-niemieckie miejsca pamięci'. Already available from the series: Hans Henning Hahn and Robert Traba (eds.), Deutsch-Polnische Erinnerungsorte, vol. 3: Parallelen (Paderborn, 2012). 
multilateral ones, when Hungarian memories are placed in a comparative context, this tends to mean, above all, self-critical comparisons with Germany. Such comparisons with Germany in terms of how the two societies have dealt with and currently remember the twentieth century are a recurrent part of Hungarian discussions, especially in the broader public sphere, even if comparisons with neighbouring countries such as Romania or Slovakia would be more adequate and the study of regional entanglements certainly seems like a more pressing concern.

Whether these, in our opinion, more urgent and necessary efforts to cooperate in memory research projects shall soon be made is currently far from certain. What is clear is that if they are not made, Hungarian scholars would have a hard time achieving the level of international integration they might substantially profit from. If current trends continue, they might lose further ground to international scholars who discuss Central and Eastern European issues in international languages and in comparative and transnational manner: the level of integration of at least some Hungarian references into broader European discussions and the international relevance of scholars from Hungary might diverge even further. 